\title{
Familial platelet disorders with a predisposition to acute myelogenous leukaemia: a RUNX1 update
}

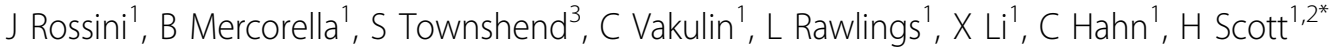 \\ From Familial Aspects of Cancer 2011 Research and Practice: A combined meeting of kConFab, Australian \\ Breast Cancer Family Study, Australian Colorectal Cancer Family Study, Australian Ovarian Cancer Study, \\ Family Cancer Clinics of Australia and New Zealand and kConFab \\ Kingscliff, Australia. 23-26 August 2011
}

\section{Background}

Familial platelet disorder with a predisposition to acute myelogenous leukaemia (FPD-AML, omim\#601399) is an autosomal dominant disorder that is linked to mutations within the RUNX1 gene. The RUNX1 gene, present on 21q22.1, plays a role as a regulatory switch in both embryonic and adult haemopoietic development. Heterozygous mutations in RUNX1 are a common feature in FPD-AML with different prognostic outcomes reported to be attributable to the location of the mutation within the protein domains.

The Australian Familial Haematological Cancer Study (AFHCS) currently has 56 Australian families registered with predispositions to haematological malignancy. RUNX1 mutations have been found in 11 patients from 3 families diagnosed with AML. This figure is predicted to be higher if screening occurred when FPD was first detected.

The IMVS, Adelaide, now offers full RUNX1 gene screening. To date, we have screened 25 individuals and confirmed germline mutations in 2 AFHCS families. We have reported a novel germline heterozygous nonsense mutation (c.958C > T, p.Arg320X), and a deletion of exons 2,3 and 4. (c.59-32857_508+2502del).

Recent research is highlighting the role of monoallelic RUNX1 mutations in the generation and progression of pre-leukaemic FPD to AML. The evidence suggests that different prognostic outcomes are dependent on the impact the mutation has on the final product, although there is a wide degree of genetic heterogeneity observed.

\footnotetext{
* Correspondence: hamish.scott@health.sa.gov.au

${ }^{1}$ Institute of Medical and Veterinary Science, Adelaide, SA, Australia

Full list of author information is available at the end of the article
}

This has implications for the management and treatment options available to individuals affected. It has also proved useful in selecting family members negative for the familial mutation who may be suitable as bone marrow donors.

\section{Author details}

${ }^{1}$ Institute of Medical and Veterinary Science, Adelaide, SA, Australia. ${ }^{2}$ Centre for Cancer Biology, SA Pathology, Adelaide, SA, Australia. ${ }^{3}$ Genetics Services of WA, KEMH, Subiaco, WA, Australia.

Published: 12 April 2012

doi:10.1186/1897-4287-10-S2-A64

Cite this article as: Rossini et al:: Familial platelet disorders with a predisposition to acute myelogenous leukaemia: a RUNX1 update. Hereditary Cancer in Clinical Practice 2012 10(Suppl 2):A64.

Submit your next manuscript to BioMed Central and take full advantage of:

- Convenient online submission

- Thorough peer review

- No space constraints or color figure charges

- Immediate publication on acceptance

- Inclusion in PubMed, CAS, Scopus and Google Scholar

- Research which is freely available for redistribution 